\title{
Low Vitamin D Status in a Cancer Patient Population from Franconia, Germany
}

\author{
Rainer Johannes Klement Petra S. Koebrunner Kelley Krage \\ Reinhart A. Sweeney \\ Department of Radiation Oncology, Leopoldina Hospital, Schweinfurt, Germany
}

\author{
Keywords \\ Calcitriol · Cholecalciferol · COVID-19 · Radiotherapy · \\ SARS-CoV-2
}

\begin{abstract}
Background: Vitamin D has been shown to be associated with reduced risk and severity of COVID-19 and exerts regulating effects on all hallmarks of cancer. The goal of this study was to analyze the vitamin D status of a cancer patient cohort from our clinic in the Franconian region, Germany. Methods: 25 -hydroxyvitamin D concentrations were available for 116 patients included in prospective trials in our clinic. Associations of vitamin D with anthropometric and blood parameters were investigated using Kendall's T correlation coefficients and linear regression. Results: A total of 57 patients (49.1\%) were vitamin D deficient ( $<20 \mathrm{ng} /$ $\mathrm{mL}$ ), and $92.2 \%$ did not meet the recommended vitamin $\mathrm{D}$ level of $40 \mathrm{ng} / \mathrm{mL}$. There was a strong negative association between vitamin $\mathrm{D}$ and leukocyte count $(\tau=-0.173, p=$ 0.007 ) and C-reactive protein concentration ( $\tau=-0.172, p=$ 0.007). In linear regression, the most important variables for predicting vitamin D levels were (in order of decreasing importance) season, fat mass index, platelet, and leukocyte count. Conclusions: Despite appeals towards medical societies to target widespread vitamin D deficiency in Germany more than 10 years ago, our data indicate that these have been without avail. Low vitamin D levels in cancer patients should be corrected using reasonable sun exposure and supplements.

(c) 2020 S. Karger AG, Base
\end{abstract}

Niedriger Vitamin D Status in einer unterfränkischen Population von Tumorpatienten

\section{Schlüsselwörter}

Calcitriol · Cholecalciferol · COVID-19 · Strahlentherapie · SARS-CoV-2

\section{Zusammenfassung}

Hintergrund: Es wurde gezeigt, dass Vitamin D mit einem reduzierten Risiko für die Ansteckung mit SARS-CoV-2 und leichteren Verläufen von COVID-19 assoziiert ist; zudem wirkt Vitamin D bei allen kennzeichnenden Merkmalen einer Krebserkrankung mitregulierend. Das Ziel dieser Studie war deshalb, den Vitamin D Status einer Kohorte von Krebspatienten aus unserer Klinik in Unterfranken zu erheben. Methoden: Für 116 Patienten wurde innerhalb prospektiver Studien die 25-Hydroxyvitamin D Konzentration gemessen. Assoziationen zwischen Vitamin D und anthropometrischen sowie Blutparametern wurden mittels Kendall's Korrelationskoeffizienten $\mathrm{\tau}$ und linearer Regression untersucht. Ergebnisse: Insgesamt wiesen 57 Patienten (49,1\%) einen Vitamin-D Mangel $(<20 \mathrm{ng} / \mathrm{mL})$ auf, und $92,2 \%$ lagen unterhalb des empfohlenen Vitamin D Spiegels von $40 \mathrm{ng} / \mathrm{mL}$. Wir fanden eine starke negative Korrelation zwischen Vitamin D und der Anzahl an Leukozyten ( $\tau=-0.173, p=0.007$ ) sowie C-reaktivem Protein ( $\tau=-0.172, p=0.007)$. Die wichtigsten Variablen zur Vorhersage des Vitamin D Wertes in der linearen Regression waren (der Wichtigkeit nach) die Jahreszeit, der Fettmasseindex, die Thrombozyten- und die Leukozyten-Zahl. 
Schlussfolgerungen: Trotz dringender Appelle an medizinische Fachgesellschaften vor über 10 Jahren, etwas gegen weitverbreiteten Vitamin D Mangel zu unternehmen, zeigen unsere Daten, dass diesbezüglich immer noch enormer Handlungsbedarf besteht. Niedrige Vitamin D Spiegel von Tumorpatienten sollten mittels vernünftiger Sonnenexposition und Nahrungsergänzungsmitteln behoben werden.

(c) 2020 S. Karger AG, Base

\section{Introduction}

Vitamin D, though primarily recognized for its impact on bone health, also has many roles in immune function and defense [1] that are of particular interest at this time, in light of the current global outbreak of the severe acute respiratory syndrome coronavirus-2 (SARS-CoV-2). Vitamin $\mathrm{D}$ can be absorbed from the diet in the form of either cholecalciferol $\left(D_{3}\right)$ or ergocalciferol $\left(D_{2}\right)$, or it can be synthesized in the skin from 7-dehydrocholesterol through a chemical reaction that is dependent on sun exposure. Vitamin D from both sources gets activated via hydroxylation reactions in the liver and kidney to 1,25 dihydroxyvitamin $\mathrm{D}(1,25(\mathrm{OH}) 2 \mathrm{D})$. As $1,25(\mathrm{OH}) 2 \mathrm{D}$, or calcitriol, vitamin $\mathrm{D}$ has a number of anti-viral and immune-modulating effects that have shown promise in the prevention and treatment of SARS-CoV-2. For instance, viruses are known to disturb the integrity of tight junctions and adherens junctions, increasing the probability of superinfection [2], while vitamin $\mathrm{D}$ has been found to strengthen them [3]. Additionally, vitamin D is likely to reduce inflammatory response by promoting expression of the angiotensin-converting enzyme 2 (ACE2) gene [3]. SARS-CoV-2 has been shown to exploit ACE2 in the renin-angiotensin pathway, activating severe cytokine activity and producing poorer prognosis for those infected [4]. Vitamin D can support the immune system by opposing this downregulation of genes and therefore evading acute or fatal inflammatory storms caused by the virus.

Patients presenting to our radiotherapy clinic are a high-risk population for contracting the disease caused by SARS-CoV-2 (COVID-19) due to the tumor itself, the cancer treatment, and various comorbidities that are often associated [5, 6]. Additionally, some recommendations suggest that anyone who has positively tested for SARS-CoV-2 should be assessed for withholding anticancer therapy until they are deemed medically cleared [7]. However, others have pointed out that an interruption of radiotherapy treatment is clinically unacceptable [6]. Thus, it is crucial in our practice to avoid the contraction of the virus in patients to prevent the spread in a fully running and populated facility. Under the hypothesis that vitamin D may provide some protection against contract- ing COVID-19, the aim of this article is to assess the typical vitamin $\mathrm{D}$ status of patients seen in our clinic for radiotherapy, and to draw conclusions regarding the recommendation of vitamin D supplementation to cancer patients.

\section{Materials and Methods}

\section{Study Cohort}

The cohort for this study consists of 116 cancer patients who were referred to our clinic (latitude $50.05^{\circ} \mathrm{N}$ ) for curative radiotherapy. One part of the sample is composed of patients from the KETOCOMP study whose aim was to test the effects of a ketogenic diet on body composition in patients with breast, rectal, and head and neck cancer $[8,9]$. The KETOCOMP study had been approved by the ethics committee of the Bavarian Medical Association (Landesaerztekammer Bayern) and registered under ClinicalTrials.gov (Identifier: NCT02516501, registered on 08/06/2015). Vitamin D assessment was not part of the original KETOCOMP study protocol, but was added to the blood panel starting from August 2016 in breast cancer patients $(n=60)$, from October 2017 in rectal cancer patients $(n=24)$, and from March 2018 in head and neck cancer patients $(n=16)$. A second part of the sample for this analysis consists of 13 breast cancer patients participating in a small pilot study to test the effects of a Paleolithic diet and daily outdoor walking during radiotherapy on body composition and vitamin D levels [10]. Finally, 3 high-grade glioma patients planning to consume a ketogenic diet concurrent with radiotherapy make up the third part of our present cohort.

Besides vitamin D, we collected baseline anthropometric and patient characteristics, blood cell counts, blood glucose, C-reactive protein (CRP), and parathyroid hormone (PTH). The latter was included in our experimental blood panels since end of September 2019, so that only 54 patients had their PTH level measured.

The anthropometric variables we used for this assessment were body mass index, fat mass index (FMI), and skeletal muscle mass index (SMI), all of which were obtained from a baseline height and bioimpedance analysis measurement (seca 515/514 mBCA; seca Deutschland, Hamburg, Germany) as described previously [8]. Briefly, measurements were performed in underwear after an overnight fast with an empty bladder. Bioelectrical phase angle at $50 \mathrm{kHz}$ was also included as a variable for this study, because Barrea et al. [11] have found a strong positive association between phase angle and $25(\mathrm{OH}) \mathrm{D}$ concentrations. After bioimpedance measurements, patients underwent blood withdrawal. All blood samples were analyzed by the hospital laboratory, and serum $25(\mathrm{OH}) \mathrm{D}$ concentration was obtained by the ECLIA method.

\section{Statistical Analysis}

The cohort was split into different groups based on either tumor entity or the season of the year. The Shapiro-Wilk test confirmed that several variables of interest, e.g. vitamin D levels, were not normally distributed within particular groups. Therefore, the non-parametric Kruskal-Wallis test was used to test for betweengroup differences of continuous variables. Fisher's exact test was used for between-group differences of categorical variables. $p$ values $<0.005$ were considered significant in the sense of providing strong evidence against the null hypothesis [12]. Correlation analysis between vitamin D levels and other variables of interest was conducted using Kendall's $\tau$ as the correlation coefficient, because it is more robust and slightly more efficient than the Spearman's rank correlation measure [13]. Finally, a linear regression model 
Table 1. Baseline characteristics of our sample

\begin{tabular}{|c|c|c|c|c|c|}
\hline Parameter & $\begin{array}{l}\text { Rectal cancer } \\
(n=24)\end{array}$ & $\begin{array}{l}\text { Head and neck cancer } \\
(n=16)\end{array}$ & $\begin{array}{l}\text { Breast cancer } \\
(n=73)\end{array}$ & $\begin{array}{l}\text { High-grade glioma } \\
(n=3)\end{array}$ & $p$ value \\
\hline Age, years & $59(38-77)$ & $62(50-76)$ & $57(25-78)$ & $66(45-70)$ & 0.0089 \\
\hline \multirow[t]{2}{*}{ Gender } & Male: $17(71 \%)$ & Male: $10(62.5 \%)$ & Male: 0 & Male: $2(66 \%)$ & $<0.001$ \\
\hline & Female: 7 (29\%) & Female: $6(37.5 \%)$ & Female: 73 (100\%) & Female: $1(33 \%)$ & \\
\hline BMI, kg/m² & $25.4(19.8-39.4)$ & $24.7(16.4-33.8)$ & $25.5(18.8-45.2)$ & $24.0(20.0-26.5)$ & 0.566 \\
\hline FMI, $\mathrm{kg} / \mathrm{m}^{2}$ & $8.3(1.6-18.7)$ & $7.3(2.5-15.9)$ & $9.6(4.9-24.7)$ & $7.6(6.1-7.8)$ & 0.0071 \\
\hline SMI, $\mathrm{kg} / \mathrm{m}^{2}$ & $8.7(5.9-10.4)$ & $7.6(4.3-12.3)$ & $7.1(5.2-10.2)$ & $7.7(5.7-9.2)$ & $<0.001$ \\
\hline Phase angle, ${ }^{\circ}$ & $5.0(3.7-6.6)$ & $4.3(3.7-5.9)$ & $4.8(3.7-5.9)$ & $4.4(3.8-4.8)$ & 0.0294 \\
\hline \multirow[t]{2}{*}{ Diabetes } & No: $21(88 \%)$ & No: $15(94 \%)$ & No: 69 (95\%) & No: $3(100 \%)$ & 0.536 \\
\hline & Yes: $3(12 \%)$ & Yes: $1(6 \%)$ & Yes: $4(5 \%)$ & Yes: 0 & \\
\hline Vitamin D, ng/mL & $19.5(5.9-90.9)$ & $18.3(8.6-31.7)$ & $20.4(6.8-49.9)$ & $18.1(14.2-18.2)$ & 0.416 \\
\hline $\mathrm{PTH}^{\mathrm{b}}$ & $40.1(27.3-58.9)$ & $37.1(22.4-48.2)$ & $37.1(16.6-75.8)$ & $48.9(27.8-51.2)$ & 0.729 \\
\hline Glucose, $\mathrm{mg} / \mathrm{dL}$ & $104(78-218)$ & $109(94-191)$ & $99(81-179)$ & $100(92-130)$ & 0.0035 \\
\hline $\mathrm{CRP}, \mathrm{mg} / \mathrm{L}$ & $3.4(0.2-38.5)$ & $4.3(0.4-35.9)$ & $1.7(0.1-126.2)$ & $3.8(0.4-7.2)^{\mathrm{a}}$ & 0.015 \\
\hline Leucocyte count, $10^{3} / \mu \mathrm{L}$ & $6.3(3.9-10.1)$ & $8.1(4.0-17.2)$ & $5.9(2.9-12.1)$ & $9.7(7.0-14.1)^{\mathrm{a}}$ & 0.0050 \\
\hline Erythrocyte count, $10^{6} / \mu \mathrm{L}$ & $4.8(4.1-5.6)$ & $4.6(3.5-5.4)$ & $4.5(3.2-5.6)$ & $4.6(4.4-5.0)^{\mathrm{a}}$ & 0.035 \\
\hline Platelet count, $10^{3} / \mu \mathrm{L}$ & $246(187-416)$ & $272(109-613)$ & $241(72-406)$ & $239(213-413)^{\mathrm{a}}$ & 0.261 \\
\hline
\end{tabular}

Continuous variables are presented as median (range) and categorical variables as counts (percentages). ${ }^{\text {a }}$ Missing for one patient. ${ }^{\mathrm{b}}$ Measured in 10 rectal cancer, 8 head and neck, 33 breast cancer, and 3 glioma patients.

for predicting vitamin $\mathrm{D}$ levels from variables of interest was constructed. Because the number of putative predictors was quite large compared to the number of patients, we used the least absolute shrinkage and selection operator (LASSO) method to identify the most important predictors [14]. The LASSO performs variable selection by shrinking the regression coefficients of less important predictors to zero. The optimal LASSO penalty parameter was found through 10 -fold cross validation, and the maximum number of predictors was set to five.

\section{Results}

Table 1 lists the baseline characteristics of the 116 patients in our cohort. The different patient groups were somewhat heterogeneous with respect to many variables of interest, but significantly differed only in SMI and blood glucose levels. Post hoc analysis using the Wilcoxon rank sum test revealed a significant SMI difference between the rectal and breast cancer groups $\left(p=1.6 \times 10^{-5}\right)$ and a significant difference in glucose levels between the breast and head and neck cancer groups $(p=0.00083)$. Fifty-seven patients $(49.1 \%)$ had $25(\mathrm{OH}) \mathrm{D}$ concentrations $<20 \mathrm{ng} / \mathrm{mL}$ (vitamin D deficiency [15]), while 36 patients $(31.0 \%)$ had levels $\geq 20 \mathrm{ng} / \mathrm{ml}$ and $\leq 30 \mathrm{ng} / \mathrm{mL}$ (vitamin D insufficiency [15]). Only 21 (18.1\%) of the patients had vitamin D levels within the laboratory reference range of 30-60 ng/mL, while 2 patients (1.7\%) exceeded this range. Since beginning of February 2020 (approximately the start of the COVID-19 epidemic in Germany) we had measured vitamin D levels in 30 patients, of which $16(53.3 \%)$ had vitamin D deficiency and
Table 2. Correlation between vitamin D concentration and several other variables of interest

\begin{tabular}{lcc}
\hline Variable & Kendall's $\tau$ & $p$ value \\
\hline Age $($ years $)$ & -0.075 & 0.242 \\
BMI $\left(\mathrm{kg} / \mathrm{m}^{2}\right)$ & -0.084 & 0.182 \\
FMI $\left(\mathrm{kg} / \mathrm{m}^{2}\right)$ & -0.119 & 0.058 \\
SMI $\left(\mathrm{kg} / \mathrm{m}^{2}\right)$ & -0.004 & 0.945 \\
Phase angle $\left(^{\circ}\right)$ & 0.061 & 0.333 \\
PTH & 0.037 & 0.693 \\
Glucose $(\mathrm{mg} / \mathrm{dL})$ & -0.082 & 0.199 \\
CRP $(\mathrm{mg} / \mathrm{L})$ & -0.172 & 0.007 \\
Leucocytes $\left(10^{3} / \mu \mathrm{L}\right)$ & -0.173 & 0.007 \\
Erythrocytes $\left(10^{6} / \mu \mathrm{L}\right)$ & -0.064 & 0.320 \\
Platelet count $\left(10^{3} / \mu \mathrm{L}\right)$ & -0.125 & 0.048 \\
\hline
\end{tabular}

For each variable the table displays Kendall's $\tau$ and the associated $p$ value for its correlation with vitamin D levels.

$10(33.3 \%)$ insufficiency; the median $25(\mathrm{OH}) \mathrm{D}$ concentration in these 30 patients was $18.2 \mathrm{ng} / \mathrm{mL}(8.5-37.3 \mathrm{ng} /$ $\mathrm{mL})$. From the whole cohort, 107 (92.2\%) patients would not have met the recommended vitamin $\mathrm{D}$ concentration of $40 \mathrm{ng} / \mathrm{mL}$ for preventing respiratory virus infection [16].

Median vitamin levels in winter, spring, summer, and fall were 15.8 (range 5.9-38), 22.4 (8.5-44.5), 23.1 (8.790.9), and 21.6 (10.6-61.4), respectively. The KruskalWallis test revealed a difference in vitamin D concentration between seasons $(p=0.010)$. Post hoc testing showed that the difference between summer and winter was sta- 


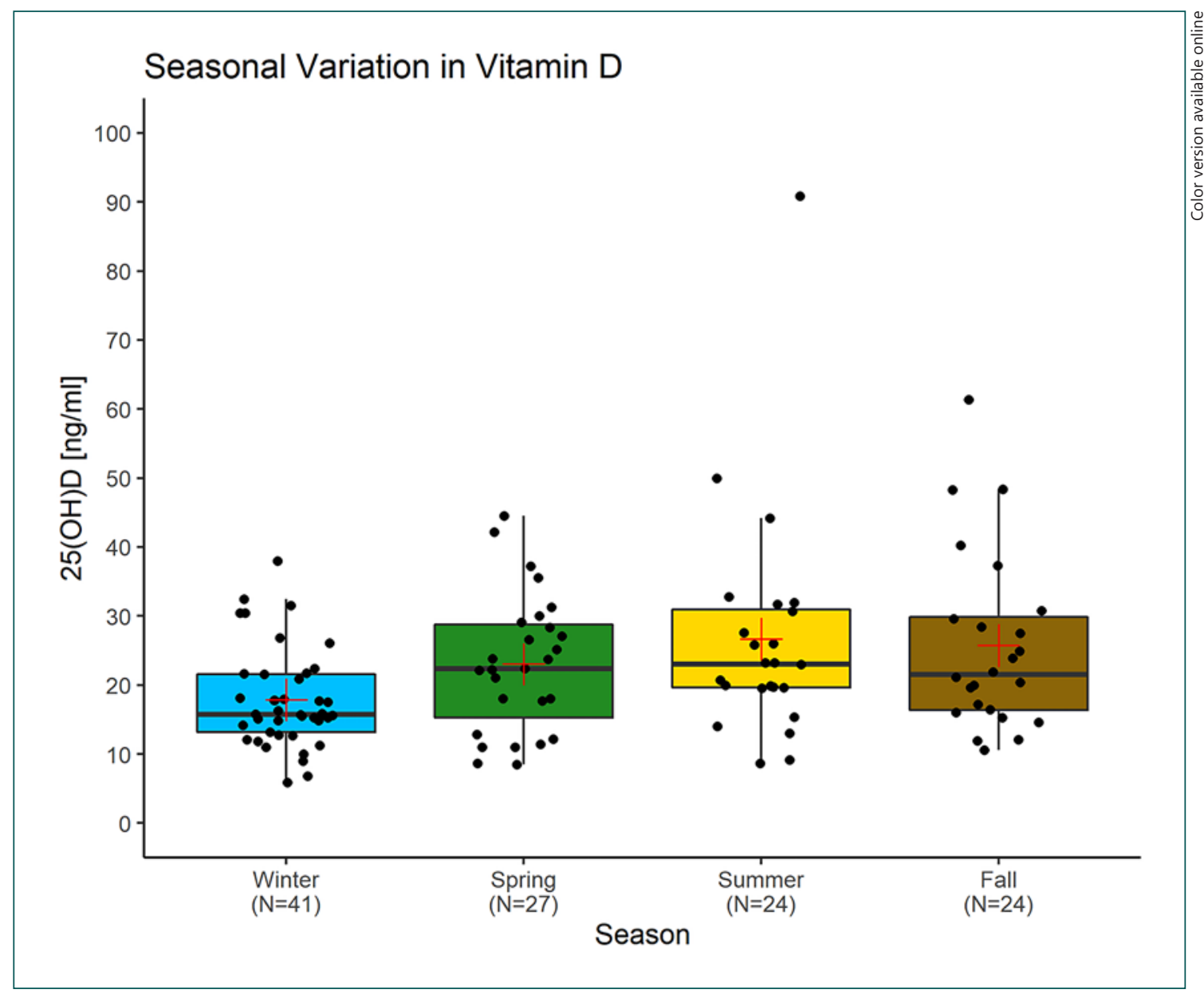

Fig. 1. Boxplot of seasonal variation in vitamin D levels. Black bars and red crosses denote the median and mean, respectively. Individual vitamin D concentrations are shown as black dots.

Table 3. Regression coefficient estimates and their standard errors for the linear regression model predicting vitamin $\mathrm{D}$ levels

\begin{tabular}{lcr}
\hline Variable & Coefficient & $p$ value \\
\hline FMI $\left(\mathrm{kg} / \mathrm{m}^{2}\right)$ & $-0.531 \pm 0.230$ & 0.023 \\
Platelet count $\left(10^{3} / \mu \mathrm{L}\right)$ & $-0.021 \pm 0.014$ & 0.145 \\
Leucocytes $\left(10^{3} / \mu \mathrm{L}\right)$ & $-0.588 \pm 0.480$ & 0.224 \\
Season: spring vs. winter & $4.92 \pm 2.76$ & 0.078 \\
Season: summer vs. winter & $8.32 \pm 2.89$ & 0.0049 \\
Season: fall vs. winter & $7.21 \pm 2.93$ & 0.016 \\
\hline
\end{tabular}

tistically significant $(p=0.0044)$, while that between winter and fall $(p=0.010)$ and winter and spring $(p=0.029)$ was less pronounced. Figure 1 shows the seasonal pattern of vitamin $\mathrm{D}$ levels among the patients.

The results of the correlation analysis are given in $\mathrm{Ta}$ ble 2. The strongest correlation was an inverse correlation between vitamin $\mathrm{D}$ concentration and leucocyte count ( $\tau=-0.173, p=0.0065)$, followed by an inverse correlation between vitamin $\mathrm{D}$ and $\mathrm{CRP}(\tau=-0.172, p=0.0071)$.
Finally, the variables given in Table 1 except diabetes and PTH were used to build a regression model for predicting vitamin $\mathrm{D}$ levels. Season of the year was also included due to its strong association with vitamin D. Based on the sample size, the allotted number of variables in the model was restricted to five. The LASSO method selected the following variables into the model: FMI, platelet count, leukocyte count, and season. A new regression model was fit with these variables, and the corresponding regression coefficients are given in Table 3.

\section{Discussion}

The aim of this work was to investigate the vitamin D status of a cancer population referred to our clinic for $\mathrm{cu}-$ rative radiotherapy in light of the current COVID-19 crisis, or more generally, the risk of contracting respiratory virus infections that may lead to interruption of radiotherapy courses. While most patients were measured prior to the SARS-CoV-2 outbreak in Germany which oc- 
curred in February 2020, our sample can be considered representative for the Franconian region within Bavaria, Germany, and spans all four seasons of the year. The chief finding was that almost half of the patients (49.1\%) were vitamin D deficient, and $92.2 \%$ did not meet the recommended minimum $25(\mathrm{OH}) \mathrm{D}$ concentration of $40 \mathrm{ng} / \mathrm{mL}$ to reduce the risk of respiratory virus infections [16] or improve cancer therapy outcomes [17]. In particular, none of the 30 patients who were evaluated since the beginning of the COVID-19 spread in Germany had reached that recommendation. The goal to have $25(\mathrm{OH}) \mathrm{D}$ concentrations exceeding $40 \mathrm{ng} / \mathrm{mL}$ should be considered an expert recommendation for optimizing the health benefits of vitamin D. In contrast, the reference ranges of many laboratories (30-60 $\mathrm{ng} / \mathrm{mL}$ in our laboratory) should be considered more of a compromise between the statistical normal range and expert recommendations.

Recently, D'Avolio et al. [18] retrospectively found that symptomatic patients testing positive for SARS$\mathrm{CoV}-2$ had significantly lower $25(\mathrm{OH}) \mathrm{D}$ concentrations (median $11.1 \mathrm{ng} / \mathrm{mL}$ ) compared to symptomatic patients with a negative test result $(24.6 \mathrm{ng} / \mathrm{dL})$. Importantly, the difference remained significant in the age group $>70$ years, which represents a risk population for COVID-19. In a German cohort of 185 consecutive COVID-19 patients, vitamin D levels $<20 \mathrm{ng} / \mathrm{mL}$ were associated with a covariate-adjusted 11.3-fold higher risk of dying from COVID-19 compared to vitamin D levels $\geq 20 \mathrm{ng} / \mathrm{mL}$ (hazard ratio 95\% CI 1.5-85.6) [19]. These data confirm the hypothesis that vitamin $\mathrm{D}$ deficiency may predispose to SARS-CoV-2 infection and drastically increase the risk of dying from COVID-19. If this hypothesis were true, it would clearly emphasize the need to monitor and - if necessary - correct vitamin D levels in cancer patients. But even outside the context of the SARS-CoV-2 epidemic, an adequate vitamin D status of at least $40 \mathrm{ng} / \mathrm{mL}$ appears beneficial in cancer prevention and treatment $[17,20,21]$. The mechanisms include regulating effects of calcitriol on all the hallmarks of cancer, including proliferation, apoptosis, angiogenesis, and cell migration [20]. For optimal cancer therapy outcomes, Gröber et al. [17] have argued to monitor and treat $25(\mathrm{OH}) \mathrm{D}$ concentrations until a target of $40-60 \mathrm{ng} / \mathrm{mL}$ is reached, in line with the recommendation of Grant et al. [16] for preventing respiratory virus infection. Unfortunately, some chemotherapeutics, in particular anthracyclines and taxanes, are able to degrade $25(\mathrm{OH}) \mathrm{D}$ and $1,25(\mathrm{OH}) 2 \mathrm{D}$ via induction of the vitamin D-degrading enzyme 24-hydroxylase [17]. In our cohort, 23 breast cancer patients had received pre-radiotherapy chemotherapy with anthracyclines or taxanes; however, their vitamin D levels (median $23.2 \mathrm{ng} / \mathrm{mL}$ ) were not significantly different from those of the 50 breast cancer patients who had received no chemotherapy (19.7 $\mathrm{ng} / \mathrm{mL})(p=0.237)$.
The natural supply of vitamin $\mathrm{D}$ consists of diet and solar UV-B radiation. The highest amounts of vitamin D can be found in fatty fish, and lower amounts in liver and eggs: $100 \mathrm{~g}$ cooked salmon or mackerel contain roughly 350 IU of vitamin D, while beef liver and eggs contain 25-30 IU (Table 6.1 in [22]). While the incorporation of these animal-based foods could be advised to patients, these values show that sufficient vitamin $\mathrm{D}$ status cannot be achieved by diet alone, making solar UV-B radiation the primary natural factor for guaranteeing healthy vitamin D levels. In German latitudes, vitamin D synthesis in the skin is not possible between October and March [22]. Accordingly, vitamin D status of German adults shows a strong seasonal trend [23]. Our data also revealed this seasonal trend of $25(\mathrm{OH}) \mathrm{D}$ concentration being lowest in winter and highest in summer, with a significant difference between summer and winter. Season was also the most significant predictor of $25(\mathrm{OH}) \mathrm{D}$ concentration in linear regression, with summer versus winter predicting $8.3 \mathrm{ng} / \mathrm{mL}$ more $25(\mathrm{OH}) \mathrm{D}(p=0.0049)$. However, even during summer, the majority of patients $(17 / 24=71 \%)$ did not reach the minimum laboratory reference value of $30 \mathrm{ng} / \mathrm{mL}$, and $9 / 24$ patients $(37.5 \%)$ had $25(\mathrm{OH}) \mathrm{D}$ concentrations $<20 \mathrm{ng} / \mathrm{mL}$. This shows that many patients have dramatically low sun exposure even during the summer months, as exposing $25 \%$ body surface to the sun for 20-60 min 3 times per week should be sufficient to avoid vitamin D deficiency (Table 7.2 in [22]). In fact, only 2 patients managed to achieve $25(\mathrm{OH}) \mathrm{D}$ concentrations $>40 \mathrm{ng} / \mathrm{mL}$ without taking any vitamin $\mathrm{D}$ containing supplements; both had tanned skin and were assessed at the end of the summer in September.

Through correlation analysis, we could show that $25(\mathrm{OH}) \mathrm{D}$ concentrations were inversely correlated with blood cell counts, viz. leucocytes, erythrocytes, and platelets (Table 2). Inverse associations of vitamin D with platelet counts $[24,25]$, erythrocyte counts $[25,26]$, and leukocyte counts [25] have also been described in the literature, but in some populations there was either no clear correlation (e.g., with leukocyte count in a Brazilian population [27]) or a positive correlation (e.g., with platelets in [28]). In the Brazilian study, there was no clear association between vitamin $\mathrm{D}$ and total leucocyte count, but a significant negative association between eosinophil count and vitamin D [27]. In our cohort, leukocytes showed the strongest inverse correlation with vitamin $\mathrm{D}$ among blood cells $(p=0.007)$, but unfortunately in this patient cohort no differentiation of the leucocytes into their subtypes had been performed.

Finally, there was moderate evidence for an inverse correlation between 25(OH)D concentrations and CRP levels (Kendall's $\tau=-0.172, p=0.0071$ ). Although usually considered an acute-phase protein, CRP is also an unspecific marker of chronic (low-grade) inflammation, 
which is characteristic of both obesity and cancer. Accordingly, we also found FMI to be inversely correlated with vitamin $\mathrm{D}$ levels, and to be a better predictor of $25(\mathrm{OH}) \mathrm{D}$ concentration than CRP when accounting for other confounding variables in linear regression with the LASSO method. The inverse association between body fat and vitamin D is well known $[11,29,30]$, and due to vitamin $\mathrm{D}$ being fat soluble and stored in body fat compartments. The reduced bioavailability of vitamin D associated with obesity has been demonstrated by Wortsman et al. [30] who showed that $24 \mathrm{~h}$ after whole body UV-B irradiation, the incremental increase in $25(\mathrm{OH}) \mathrm{D}$ concentrations was 57\% lower in obese than in non-obese subjects. Another parameter related to body composition and chronic low-grade inflammation is bioelectrical phase angle, which is a proxy for muscle mass and cell membrane integrity. Contrary to Barrea et al. [11]; however, there was no strong association between phase angle at $50 \mathrm{kHz}$ and $25(\mathrm{OH}) \mathrm{D}$ concentration in our sample. It is possible that the strength of correlation was less pronounced in our patients due to their older age and the smaller range spanned by phase angle compared to the relatively young population studied by Barrea et al. [11] which also included physically active healthy individuals with high phase angles.

In 2010, A. Zittermann estimated that improving vitamin D status in Germany could save costs of EUR 37.5 billion annually and called for action by nutrition and medical societies to erase vitamin $\mathrm{D}$ deficiency within the next 5-10 years [31]. Our data indicate that this goal has not been met in the Franconian region. The current COVID-19 crisis should be taken as a warning to re-consider the critical role of vitamin $\mathrm{D}$ for prevention of respiratory virus infection, in addition to a general improvement of outcomes for cancer patients. Vitamin D status of patients should be assessed and advice given to improve it through reasonable sun exposure, diet, and supplements. In our experience, recommending fatty animal products, 30- to 60-min daily sun exposure (optimally coupled with physical activity) and/or daily supplementation of 2,00020,000 IU vitamin D (depending on body weight and baseline value) are effective measures to eliminate vitamin D deficiency during the course of radiotherapy [10].

\section{Statement of Ethics}

The subjects (or their parents or guardians) have given their written informed consent. Most subjects were from the KETOCOMP study, which has been approved by the ethics committee of the Bavarian Medical Association (Landesaerztekammer Bayern) and registered under ClinicalTrials.gov (Identifier: NCT02516501, registered on 08/06/2015). The Paleolithic lifestyle pilot study [10] was retrospectively registered under ClinicalTrials.gov (Identifier: NCT04574323).

\section{Conflict of Interest Statement}

The authors declare that they have no conflicts of interest related to this publication.

\section{Funding Sources}

No funding has been received for conducting this study.

\section{Author Contributions}

R.J.K. and R.A.S. designed the study; R.J.K., P.S.K. and K.K. collected and analyzed the data; R.J.K. and K.K. prepared the initial manuscript; P.S.K. and R.A.S. edited the initial version of the manuscript; all authors approved the final version of the manuscript.

\section{References}

1 Hewison M. An update on vitamin D and human immunity. Clin Endocrinol (Oxf). 2012 Mar;76(3):315-25.

2 Rossi GA, Fanous H, Colin AA. Viral strategies predisposing to respiratory bacterial superinfections. Pediatr Pulmonol. 2020 Apr; 55(4):1061-73.

3 Chen H, Lu R, Zhang YG, Sun J. Vitamin D Receptor Deletion Leads to the Destruction of Tight and Adherens Junctions in Lungs. Tissue Barriers. 2018;6(4):1-13.

4 Panarese A, Shahini E. Letter: Covid-19, and vitamin D. Aliment Pharmacol Ther. 2020 May;51(10):993-5.

5 Centers for Disease Control and Prevention. People at Increased Risk for Severe Illness. https://www.cdc.gov/coronavirus/2019ncov/need-extra-precautions/people-athigher-risk.html (accessed May 29, 2020).
6 Al-Shamsi HO, Alhazzani W, Alhuraiji A, Coomes EA, Chemaly RF, Almuhanna M, et al. A Practical Approach to the Management of Cancer Patients During the Novel Coronavirus Disease 2019 (COVID-19) Pandemic: An International Collaborative Group. Oncologist. 2020 Jun;25(6):e936-45.

7 Guckenberger M, Belka C, Bezjak A, Bradley J, Daly ME, DeRuysscher D, et al. Practice recommendations for lung cancer radiotherapy during the COVID-19 pandemic: an ESTROASTRO consensus statement. Radiother Oncol. 2020 May;146:223-9.

8 Klement RJ, Sweeney RA. Impact of a ketogenic diet intervention during radiotherapy on body composition: II. Protocol of a randomised phase I study (KETOCOMP). Clin Nutr ESPEN. 2016 Apr;12:e1-6.
9 Klement RJ, Schäfer G, Sweeney RA. A ketogenic diet exerts beneficial effects on body composition of cancer patients during radiotherapy: an interim analysis of the KETOCOMP study. J Tradit Complement Med. 2019 Mar;10(3):180-7.

10 Klement RJ, Koebrunner PS, Krage K, Weigel $\mathrm{MM}$, Sweeney RA. Short-term effects of a Paleolithic lifestyle intervention in breast cancer patients undergoing radiotherapy: a pilot and feasibility study. Med Oncol. 2020 Nov;38(1): 1. doi: $10.1007 / \mathrm{s} 12032-020-01443-0$

11 Barrea L, Muscogiuri G, Laudisio D, Di Somma C, Salzano C, Pugliese G, et al. Phase Angle: A Possible Biomarker to Quantify Inflammation in Subjects with Obesity and 25(OH)D Deficiency. Nutrients. 2019 Jul; 11(8):1747. 
12 Benjamin DJ, Berger JO, Johannesson M, Nosek BA, Wagenmakers EJ, Berk R, et al. Redefine statistical significance. Nat Hum Behav. 2018 Jan;2(1):6-10.

13 Croux C, Dehon C. Influence functions of the Spearman and Kendall correlation measures. Stat Methods Appl. 2010;19(4):497-515.

14 Friedman J, Hastie T, Tibshirani R. Regularization Paths for Generalized Linear Models via Coordinate Descent. J Stat Softw. 2010; 33(1):1-22.

15 Holick MF. Vitamin D status: measurement interpretation, and clinical application. Ann Epidemiol. 2009 Feb;19(2):73-8.

16 Grant WB, Lahore H, McDonnell SL, Baggerly CA, French CB, Aliano JL, et al. Evidence that vitamin $d$ supplementation could reduce risk of influenza and covid-19 infections and deaths. Nutrients. 2020 Apr;12(4):988.

17 Gröber U, Spitz J, Reichrath J, Kisters K, Holick MF. Vitamin D: Update 2013: From rickets prophylaxis to general preventive healthcare. Dermatoendocrinol. 2013 Jun; 5(3):331-47.

18 D’Avolio A, Avataneo V, Manca A, Cusato J, De Nicolò A, Lucchini R, et al. 25-hydroxyvitamin $\mathrm{D}$ concentrations are lower in patients with positive PCR for SARS-CoV-2. Nutrients. 2020 May;12(5):1-7.
19 Radujkovic A, Hippchen T, Tiwari-Heckler S, Dreher S, Boxberger M, Merle U. Vitamin D Deficiency and Outcome of COVID-19 Patients. Nutrients. 2020 Sep;12(9):2757. doi: 10.3390/nu12092757

20 Feldman D, Krishnan AV, Swami S, Giovannucci E, Feldman BJ. The role of vitamin D in reducing cancer risk and progression. Nat Rev Cancer. 2014 May;14(5):342-57.

21 Gröber U, Kisters K, Spitz J, Adamietz IA. Vitamin D in der onkologischen Intervention: Update 2015. Dtsch Z Onkol. 2015;47(04): 173-7.

22 Holick MF, Jenkins M. Schützendes Sonnenlicht: Die heilsamen Kräfte der Sonne. 1st ed. Stuttgart: Karl F. Haug Verlag; 2005.

23 Rabenberg M, Mensink GB. Vitamin-D-Status in Deutschland. J Heal Monit. 2016;1:3642.

24 Park YC, Kim J, Seo MS, Hong SW, Cho ES, Kim JK. Inverse relationship between vitamin $\mathrm{D}$ levels and platelet indices in Korean adults. Hematology. 2017 Dec;22(10):623-9.

25 Zupo R, Castellana F, Sardone R, Lampignano L, Di Noia C, Savastano S, et al. Hydroxyvitamin $\mathrm{d}$ serum levels are negatively associated with platelet number in a cohort of subjects affected by overweight and obesity. Nutrients. 2020 Feb;12(2):474
26 Doudin A, Becker A, Rothenberger A, Meyer T. Relationship between serum 25-hydroxyvitamin D and red blood cell indices in German adolescents. Eur J Pediatr. 2018 Apr;177(4): 583-91.

27 Souto Filho JT, de Andrade AS, Ribeiro FM, Alves PA, Simonini VR. Impact of vitamin D deficiency on increased blood eosinophil counts. Hematol Oncol Stem Cell Ther. 2018 Mar;11(1):25-9.

28 Soliman AT, Eldabbagh M, Elawwa A, Saleem W. Does Vitamin D therapy affect hematological indices in adolescents with vitamin $\mathrm{D}$ deficiency? Indian J Endocrinol Metab. 2012 Jul;16(4):659-60.

29 Liel Y, Ulmer E, Shary J, Hollis BW, Bell NH. Low circulating vitamin $\mathrm{D}$ in obesity. Calcif Tissue Int. 1988 Oct;43(4):199-201.

30 Wortsman J, Matsuoka LY, Chen TC, Lu Z, Holick MF. Decreased bioavailability of vitamin D in obesity. Am J Clin Nutr. 2000 Sep; 72(3):690-3.

31 Zittermann A. The estimated benefits of vitamin D for Germany. Mol Nutr Food Res. 2010 Aug;54(8):1164-71. 